\title{
Therapeutic Practice
}

Under the telling title "Good Advice and Little Medicine”, Hal Cook has argued that sixteenth-century learned English physicians, setting themselves off from their lesser-educated competitors, primarily conducted themselves as advisors or counselors, indeed, as moral authorities. According to Cook, they saw their main task not in the treatment of diseases but in giving their patients detailed advice that was tailored to their individual constitution, thereby instructing them on how to lead a healthy life. ${ }^{387}$ A completely different picture emerges from my study of continental European sources. ${ }^{388}$ Advice on healthy living played only a modest role in everyday medical practice as soon as one looks away from royal patients or patients of very high standing. The principal task of the physician was the successful treatment of disease. Handsch's countless notes on the effectiveness (and failure) of therapeutic efforts made by himself and other physicians point in this direction, as do the preeminent place of therapy in many published curationes and observationes and the collections of experimenta, that is "tried and tested" recipes that physicians compiled for their own use.

Two basic approaches can be distinguished in the curative medical treatment of disease of the sixteenth century, namely a causal one and a specific one. Both approaches aimed at combatting and eradicating the illness as such, unlike "palliative" treatment, which, in the contemporary understanding of the term, only "cloaked" the complaints. The aim of a causal treatment was to counter the pathological process within the body and/or to support nature in her battle against the disease. A specific treatment, on the other hand, relied on the hidden powers that inhered - as experience had taught - in specific medicinal plants and medications.

Treatment with medicinal plants known as specifics - we will be returning to this in greater detail later on - engendered considerable problems for the physicians' public image. It put them in dangerous proximity to the medicine of the non-academically trained healers, the empirici, as physicians often called them, who, according the physicians' critique, relied only on their all too often

387 Cook, Good advice (1994).

388 For seventeenth-century England, Cook notes a striking change in the ideal, away from the physician as an advisor, and a more active therapeutic role, which threatened the professional authority of the physicians (ibid., pp. 21-29). The extent to which the conditions in England and in continental Europe were really that different in the sixteenth century - for example, due to a greater dependence of English physicians on a small number of wealthy patients - and the extent to which the printed medical sources used by Cook may convey a distorted picture of ordinary medical practice in England is open to debate.

Ә Open Access. (c) 2022 Michael Stolberg, published by De Gruyter. (cc) BY-NC-ND This work is licensed under the Creative Commons Attribution-NonCommercial-NoDerivatives 4.0 International License. https://doi.org/10.1515/9783110733549-009 


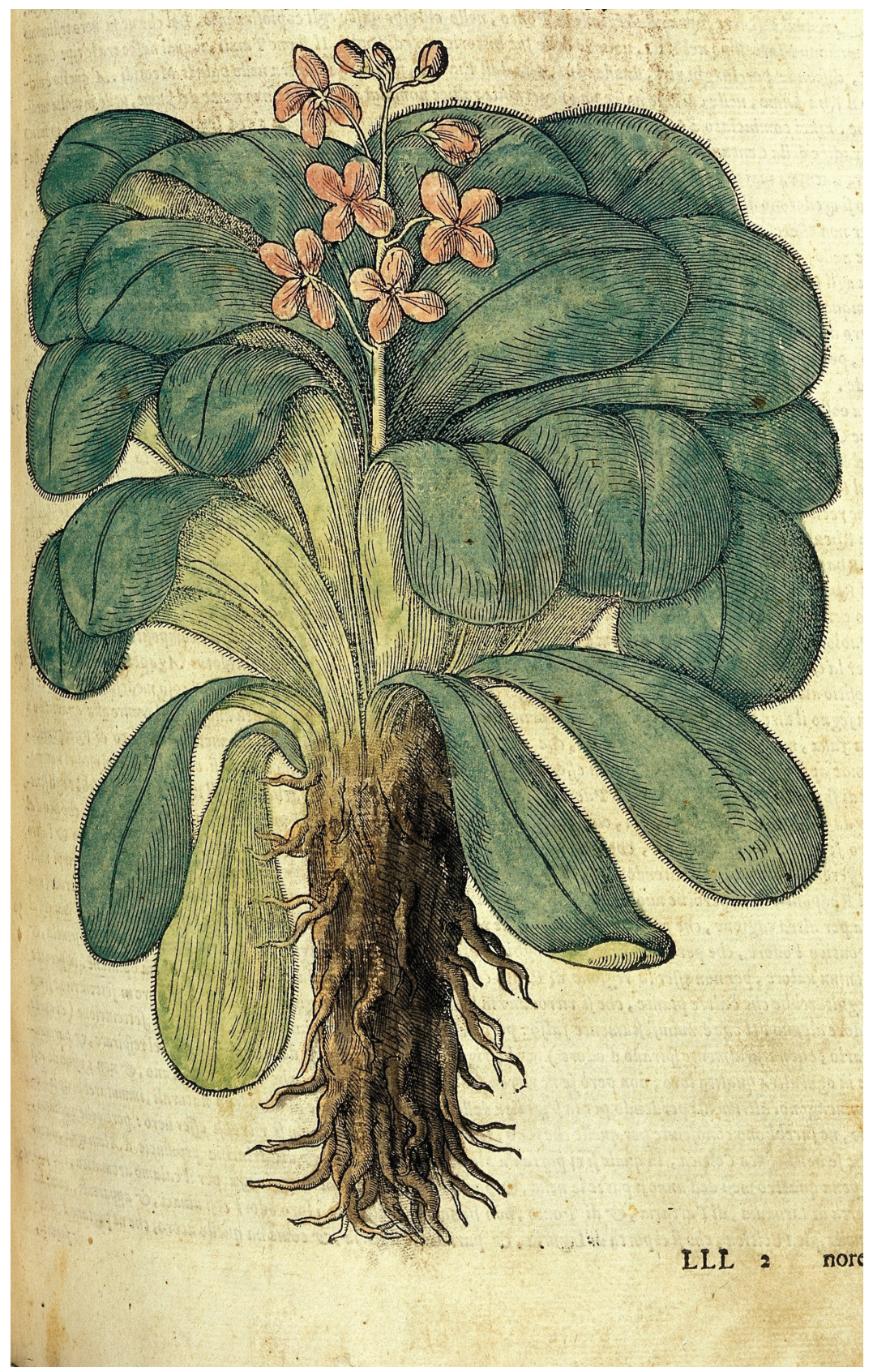

Fig. 6: Rheubabarum in: Pietro Andrea Mattioli, I discorsi nelli sei libri di Pedacio Dioscoride Anazarbeo, Venice 1568, Wellcome Collection, London. 
deceptive experience when treating patients. The causal approach to treatment, on the other hand, accorded far better with the contemporary ideal of the rational physician who, thanks to his vast knowledge of the literature and his ability to decipher the mysterious pathological processes within the body, was able to target and influence the forces at work there. The causal approach was central in medical curricula and teaching activities and predominated by far in day-today medical practice.

Because the vast majority of illnesses were attributed to a harmful, preternatural fluid or volatile matter, efforts to treat the internal cause of an illness generally involved an emptying or purging of the morbid matter. In addition, physicians turned - especially following a successful purging of morbid matter - to remedies that would "strengthen" or "restore" (roborativa, confortativa) individual organs and their faculties. ${ }^{389}$ Particularly widespread were the cordialia, that is heart-strengthening remedies; the term "cordial" for a fortifying remedy or stimulating preparation continues to be in use today. ${ }^{390}$ Handsch praised sweetened wine with amarella cerosa, among other things. ${ }^{391}$ Other widely-used preparations were manus Christi, confections, and other heavily sweetened remedies. ${ }^{392}$ Serving as stomachalia were bitter substances like zedoary $^{393}$ and the aloe-containing hiera picra, which Gallo praised as an excellent remedy for the stomach. ${ }^{394}$ Still today, we find traces of this tradition in the present-day use of bitters for the stomach.

\section{Cleansing and Purgative Remedies}

By far, the most common means of treating illness in the early modern period was administering purgatives. In a literal sense, these were cleansing remedies; we find the same linguistic root in "purgatory" (Latin: "purgatorium"), where the soul was cleansed of its sins.

389 Cod. 11183, fol. 381v.

390 Ibid., fol. 374 r.

391 Cod. 11207, fol. 195r.

392 Cod. 11183, 488v; Cod. 11207, fol. 224v; at that time, "manus Christi” could refer to various medicines, including rose sugar with musk, a remedy which, according to Hieronymus Brunschwig, strengthened the heart and brain (Brunschwig, Großes Destillierbuch (1512), fol. 152r); the term was also used for castor oil.

393 Cod. 11183, fol. 478v, "Carophylli" and "Zedoaria”.

394 Cod. 11207, fol. 208v. 
A purgative was considered to be any remedy that promoted the evacuation of impure matter. In widespread use were cassia, manna, and rhubarb (Fig. 6), but there were numerous others. The aim in administering purgatives was to free the body - generally via the bowels, and less often via other passageways of the raw or putrid pathological humors to which the vast majority of illnesses were ascribed. ${ }^{395}$ Handsch, following Gallo, gave the illustrative name of "cacatorios" to remedies that emptied the bowels. ${ }^{396}$ The central position of purgatives in the treatment of illness reflected the paramount significance of insufficiently concocted waste matter and of foul morbid matter of all kinds in the contemporary understanding of dieseases. In the rare diagnosis of intemperies, which did not involve morbid matter, purgatives were not indicated. ${ }^{397}$

If morbid waste matter had amassed in the stomach and/or intestines, one could hope to empty this matter directly. With their own eyes, people could see the stinking, slimy matter that came out. ${ }^{398}$ As a fundamental principle, it was indicated for the bowels to be cleansed at the outset of treatment so as to get rid of the worst of the waste matter. ${ }^{399}$ But purgatives also served to void waste matter and morbid matter found in the rest of the body. Here, a physician could explain, for example, that "The purgative will cleanse the blood". ${ }^{400}$ In such cases - Handsch brought this up repeatedly in his notes - the physician usually had to first administer preparatory remedies, however. ${ }^{401}$ The idea was to mobilize the morbid matter through the use of "reducing" (minorativa) or "softening" (lenitiva) remedies, to expediate its concoction as much as possible through digestiva, and to open the way to the bowels for it. ${ }^{402}$ According to Handsch, one could explain, "Before the purgative, one has to give light drinks that soften, separate, and strip off the coarse blood and slime and open the obstruction" and that afterwards the purging would go well. ${ }^{403}$ Here, physicians took recourse to warming medications in the form of sweet syrups and electuaries,

395 Cod. 11210, fol. 57v.

396 E.g. Cod. 11205, fol. 557v and fol. 593v; Cod. 11207, fol. 129v.

397 Cod. 11207, fol. 45r, on Gallo's criticism of physicians who all too often purged; the occasion, however, was the Emperor's trembling heart, a disease which at that time could only be indirectly attributed to a morbid matter (cf. Heusinger, Das zitternde Herz [2021]).

398 Cod. 11204, fol. 28r, "multum phlegmatis eduxerunt cum stercoribus".

399 Cod. 11183, fol. 410v.

400 Cod. 11206, fol. 168r: "Die Purgatz wirt das Geblütt reinigen”.

401 Cod. 11210, fol. 58r.

402 Cod. 11205, fol. 312r, on Ulrich Lehner's “ordo curationis”; similarly, referring to Avicenna's Canon medicinae, Cod. 11240, fol. 2r.

403 Cod. 11205, fol. 595r: "Man mus vor der Purgatz leichte Trenckel geben, die das grobe Blutt und Schleym erweichen, zertrennen, abstreiffen und dieVerstopffung eröffnen”. 
which supported the work of the vital heat. ${ }^{404}$ Explaining this process to an elderly patient, Handsch said that they "soften and open the obstruction in the veins so that the bad humor may follow in the purging". ${ }^{405}$ Handsch noted down how one might explain this to future patients: "The slime is caked on, glued on; before giving the purgatives one has to use the syrups to soften, detach and strip if off, like one has to use soap that eats or bites into the dirt, because without it the water washes nothing off." ${ }^{406}$ Another formulation was: "One first has to separate and collect the bad humor that is mixed and blended into the good blood using syrups, and open up the veins inside, so the purgative will not draw out the good with the bad but only the bad, and likewise so the passageways in the veins do not remain obstructed."407

Physicians and patients alike measured the efficacy of a purgative above all by the number of stools it produced. It was often between five and ten. One sick young nobleman, for example, had nine "jiggly" "snaking” stools after taking a purgative. ${ }^{408}$ For the wife of a chancery clerk, it was twelve glistening, slimy stools. ${ }^{409}$ With powerful purgatives, patients occasionally reported significantly more bowel movements. After taking a purgative, Philippine Welser first defecated fourteen times and later twenty times more. Her stomach was subsequently in turmoil, but calmed down again after she ate and drank wine. ${ }^{410}$ In the case of Felix Platter, aloe pills caused such "great urge" that he had sixteen bowel movements and then fell unconscious. ${ }^{411}$ After taking a purgative, sick Toppertzer produced twenty-eight stools, ${ }^{412}$ while in the case of Florianus, who was ill with the French disease, it was fifty. ${ }^{413}$

404 Cod. 11210 , fol. 58 r.

405 Cod. 11205, fol. 13v.

406 Ibid., fol. 296r: "Der Schleiym ist angebacken, angekleistert"; "ehe man die Purganzien gibt, mus man yn zuvor durch die Syrop[is] erweichen, ablösen, und abstreiffen, wie man den Unfalt zuvor mit der Seyffen ausetzen, aber [oder] ausbeysen mus, zuvor wescht das Wasser nichts ab." He added at the margin: "und die Verstopfung ynn Adern und Lebern erofnen, das die böse Feuchtikeiten mit der Pürgatz zu gange kommen mögen" ("and to open the obstruction of the vessels and of the liver, so that the evil fluids may start moving with the purgative").

407 Ibid., fol. 427v; similarly Cod. 11206, fol. 127v.

408 Cod. 11207, fol. 30r: "Man mus die böse Feuchtickait, die under das gutte Blutt gemischt und gemengt ist, zuvor mit den Sirupen absondern, zusammenbringen, unnd das Geeder inwendig eroffnen, damit die Purgatz nicht das Gutte mit dem Bösen, sondern das Böse nur allein weg ziehe, item das die Genge ym Geeder nicht gestopfft seindt.”

409 Cod. 11183 , fol. $458 \mathrm{v}$.

410 Cod. 11204, fol. 17r.

411 Platter, Lebensbeschreibung (1976), p. 219.

412 Cod. 11205, fol. 274 r.

413 Ibid., fol. $244 r$. 
Purgatives were also administered as a precautionary measure, especially at the beginning and at the end of the winter. ${ }^{414}$ In certain situations, it was better not to administer them, however, because they threatened to disrupt the efforts of nature to evacuate the waste and morbid matter herself. When there were indications that a "critical" evacuation via the sweat was taking place, or when a skin rash formed, or just before an expected menstruation was to take place, one ran the risk of disturbing the natural evacuations if a purgative was administered. ${ }^{415}$ Handsch wrote that patients and their relatives would moreover sometimes resist taking a purgative because the patient had already had plenty of bowel movements and was hardly eating anything. In their opinion, there was nothing left to purge. ${ }^{416}$ One then had to explain to them that the purgative attracted waste and morbid matter from beyond the intestines, from the rest of the body. For this reason, cleansing and emptying was most definitely still indicated. ${ }^{417}$

Physicians worked to adapt their prescriptions and dosages to the clinical picture and the physical constitution of the patient. Purgatives varied in strength and, as experience taught, the same remedy could produce different effects in different patients. For this reason, Handsch made a point of asking patients about their usual bowel movements and their experience with purgatives. In this way he would be better able to estimate the effects of the purgative he was about to prescribe. ${ }^{418}$ As experience taught, excessive evacuation could strain the sick person's body tremendously, even if one ordered, as Lehner did, a fortifying remedy like rose sugar or sweet meats to be taken afterward. ${ }^{419}$ Several times, Handsch wrote about the tragic cases of hyperpurgatio. After Gallo had given her a purgative, a sick patient called Marsalkowa had up to eight bowel movements every day for several days and her tongue became completely dried out. In the end she died and people said it was the physician who had killed her. ${ }^{420}$ A young, vigorous nobleman died in the hospital after Gallo gave him a powerful purgative that produced almost thirty bowel movements and weakened him greatly. ${ }^{421}$ The same thing had happened in the case of Handsch's patient Fröhlich. Another case was

414 Cod. 11207, fol. 102v.

415 Cod. 11205, fol. 334r; Cod. 11238, fol. 130r; Cod. 11240, fol. 35v.

416 Ibid., fol. $287 \mathrm{v}$.

417 Cod. 11206, fol. 146r-v.

418 Cod. 11205, fol. 294r.

419 Ibid., fol. 312r.

420 Ibid., fol. 299r.

421 Cod. 11207, fol. 214v. 
that of an old woman in Venice who, after taking cassia, had almost a hundred stools; she died as well. ${ }^{422}$

The purgative must not be too weak either. Patients desired a copious, powerful evacuation and sometimes they explicitly noted the positive effects of the purgative. ${ }^{423}$ If the expected stool failed to materialize, the physician had made a mistake in their eyes. When Handsch gave a young female patient a purgative made with senna and she had only two bowel movements, she was dissatisfied. ${ }^{424}$ Further, if the purgative itself was not evacuated along with the stool due to its insufficient strength, it could also produce cramps and other unpleasant abdominal complaints. ${ }^{425}$ In the case of some diseases, like podagra, further dangers loomed. According to Gallo, if the purgative was too weak, it would merely mobilize the morbid matter without successfully voiding it. At that point, it might relocate to a new place in the body and get up to mischief there. ${ }^{426}$

The choice of the proper remedy was based on more than the physical constitution and the individual sensitivity of the patient. The ideal purgative would attract and evacuate the morbid matter alone. ${ }^{427}$ In practice - and for this reason purgatives often had a weakening effect on the body - good, useful matter was often evacuated along with the "evil" matter. Concerning this, Handsch wrote, "No physician's purging only heals, From the good he also steals". ${ }^{428}$ The physician had to at least try, however, to choose a remedy that would more or less target the morbid matter in question and evacuate it. From his reading of Galen, Handsch had gathered that a purgative would attract morbid matter that was similar to it. ${ }^{429}$ The question remained, however, as to how, based on which criteria, the physician could determine this similarity. Ultimately, it appears that physicians relied on what they knew from experience. According to Mattioli, senna was especially well suited to emptying burnt matter. ${ }^{430}$ Fracanzano prescribed a purgative that would target "salty humors" specifically. ${ }^{431}$

\footnotetext{
422 Ibid, fol. 152r.

423 Ibid., fol. 30v.

424 Cod. 11205, fol. 294 r.

425 Ibid., fol. $294 \mathrm{r}$.

426 Cod. 11207, fol. 197r. iron, see Temkin, Fernel (1972).

428 Cod. 11206, fol. 168v.

429 Cod. 11207, fol. 213v.

430 Cod. 11205, fol. 287v and fol. 413v.

431 Cod. 11238, fol. 121r.
}

427 Cod. 11205, fol. 396v: "Sed vera medicina est nullum alium humorem extrahere, nisi peccantem." On the contemporary discussion about the specific attraction purgatives exerted on certain types of matter, which was sometimes compared with the effect of the load stone on 
An important alternative to administering purgatives were clysters, that is enemas. $^{432}$ They were especially called for in the case of intestinal colic or stones ${ }^{433}$ but could also serve more generally as a mild means to evacuate morbid matter. Handsch and the physicians in his professional environment often employed them and Benedetto Vittore in Bologna almost routinely prescribed them. ${ }^{434}$ When sick themselves, Mattioli and Lehner readily sought the effects of a clyster. According to Handsch, the two had had several dozen if not more than a hundred enemas done over the years. ${ }^{435}$ Whereas purgatives always came with some risk, Handsch praised the clyster as the safest of all remedies. It could be given for any illness, to a person of any age and at any time of the year. One disadvantage was, however, that the ileocecal valve, a skin fold at the boundary between the large intestine and the small intestine, which Handsch's teacher Falloppia had only recently discovered, prevented the clyster fluid from entering the small intestine, as was known from recent anatomical research. In other words, only the large intestine could be cleansed. ${ }^{436}$

Depending on the quality of the stool, the physician could add different substances to the clyster. These included traditional purgatives like cassia, hiera picra, rhubarb and manna, herbal decoctions that stimulated evacuation, as well as oils, broths, or electuaries. ${ }^{437}$ The fluid that was injected was certainly plentiful. Handsch repeatedly wrote of a seidel or a pound of fluid that the patient was to keep inside his bowels for half an hour or longer. This was not always easy for patients. Sometimes the urge was too strong and the liquid was discharged after a quarter of an hour at most. ${ }^{438}$

Emetics, too, were considered purgatives in a wider sense. They primarily "cleared" the stomach. ${ }^{439}$ Sometimes patients demanded them of their own accord if they had the right symptoms. The Baroness of Hungerkasten explained, "Above the navel I kept feeling that something was lying in my stomach. [. . .] I wanted to take a stomach purgative". ${ }^{440}$ Here too, one did not want to take things too far. Those who wanted to grow old and stay healthy, Handsch noted,

432 In cases of severe pain, massive diarrhoea or bloody stool, an enema with philonium and other analgesics as well as astringents could also be given to slow down the evacuation (Cod. 11183, fol. 106r, fol. $134 \mathrm{r}$ and fol. 439v.).

433 Cod. 11183, fol. 315v; Cod. 11205, fol. 590v.

434 Biblioteca comunale Aurelio Saffi, Forlì, Fondo antico, Ms. 94.

435 Cod. 11205, fol. 201r, fol. 236r and fol. 553v; Cod. 11206, fol. 118v; Cod. 11240, fol. 36r.

436 Cod. 11210, fol. 199v.

437 Cod. 11183, fol. 39v, fol.135r and fol. 399v; Cod. 11205, fol. 268r; Cod. 11207, fol. 205v.

438 Cod. 11183, fol. 39v, fol. 274r, fol. 414v, fol. 440r and fol. 471v.

439 Cod. 11206, fol. $172 \mathrm{v}$.

440 Cod. 11205, fol. $474 v$. 
had to avoid vomiting daily and intemperately. Otherwise, they would weaken their hearing and vision, tear veins in their chest and lungs, harm their teeth, and cause headaches. ${ }^{441}$

A whole series of further medications was used to promote other excretions. Diuretica induced urination. According to Handsch's Padua notes, they were especially useful in the case of liver obstructions or when humors accumulated near the liver. ${ }^{442}$ Apophlegmatica, which were kept in the mouth and chewed, encouraged the production of saliva and attracted mucus from the rest of the head. ${ }^{443}$ Remedies that produced the urge to sneeze, so-called sternutatoria, helped free the nose and head of mucus and other morbid matter. 444 "A good effect from a bad cause", Handsch noted on the subject of sneezing. ${ }^{445}$ This ambivalence still finds reflection today when people say "Gesundheit!" ("health" in German) when somebody sneezes.

Contemporary pharmacology also ascribed "secondary" qualities to many medications. Their effect could be "softening" and "mitigating acrimonies", “dissolving” and "opening”, or "astringent". These effects largely derived from the primary qualities: cold, hot, dry, and moist. They too were important for the mobilization and excretion of morbid matter insofar as they liquified hardened morbid matter and widened and softened the passageways. ${ }^{446}$ Astringents could be used for undesirably strong excretions. Cooling substances like melon seeds served to mitigate hot, acrimonious humors. ${ }^{447}$

\section{Bloodletting and Cupping}

Alongside purgatives, bloodletting was the most important prophylaxis and treatment method in the early modern period. It was employed for countless illnesses. For certain diseases, such as the various fevers, the plague, and pleuritis, it was even considered indispensable. In Handsch's notebooks, there are hundreds of entries pertaining to it. Some of them come from his time as a medical student, while many others are from later years.

441 Cod. 11210, fol. 60r.

442 Ibid., fol. 64v.

443 Ibid., fol. 65r.

444 Ibid.

445 Cod. 9671 , fol. 11r.

446 Cod., 11183, fol. 487v; Cod. 11207, fol. 157v.

447 Cod. 11183, fol. 416v. 
Bloodletting was occasionally carried out as a treatment for plethora, an abundance of blood and other humors in the vessels and the body as a whole. ${ }^{448}$ In most cases, however, the aim was to expel morbid matter or pathologically changed blood. Decades before William Harvey published his new theory of the blood circulation, which would cast increasing doubt on bloodletting, ${ }^{449}$ Jean Fernel in the sixteenth century expressed his misgivings. Simply letting off blood only made sense, in his opinion, in the case of a plethora, an abundance of blood in the body. When, however, there was a cacochymy - when, as with most diseases, morbid matter was to be evacuated - bloodletting was useless, even harmful. It mostly meant that the body lost healthy blood and was weakened. According to Fernel, the morbid matter was to be voided with purging medications that drew out the specific humorem peccantem. ${ }^{450}$

Back when he was a student in Padua, however, Handsch had already noted down the powerful counterargument to Fernel's objection. Although not only harmful humors were evacuated during bloodletting, a voiding of harmful humors nevertheless took place. Nature was then better able to "vanquish" ("vincere") the fewer pathological humors that remained, and the good blood that was lost could easily be replenished from food. ${ }^{451}$ This led to the conclusion that bloodletting was a most excellent (“convenientissimum") remedy for any kind of humoral excess and it was generally the indicated treatment in cases of severe illnesses like inflammations as well as burning, malicious, or persistent fevers - illnesses, that is, against which nature had to fight a vicious battle. ${ }^{452}$ Gallo impressed upon Handsch, for example, the importance of bloodletting in the case of a jaundiced patient. There was such putrefaction in the veins that nature could not master it. ${ }^{453}$

When the blood as a whole was thought to be affected, bloodletting was usually done on a vein at the elbow. ${ }^{454}$ Quite often also the small veins of the hand were bled, especially the vena salvatella, a small vein at the back of the hand between the base of the pinky finger and the ring finger. ${ }^{455}$ Opening the smaller

448 Stengel, De venae sectione (1602) focussed on this usage.

449 Harvey, Exercitatio (1628).

450 According to Cod. 11210 , fol. 55r.

451 Ibid.

452 Ibid.

453 Cod. 11205, fol. $155 \mathrm{v}$.

454 Cod. 11210 , fol. $56 \mathrm{v}$.

455 E.g. Cod. 11193, fol. 487v; Cod. 11207, fol. 92v; Cod. 11238, fol. 132r; Cod. 11240, fol. 97v and fol. $127 \mathrm{r}$. 
veins was generally considered to have a less weakening effect. ${ }^{456}$ For this reason, Handsch's teacher Lehner preferred this vein when letting the blood of noblewomen. ${ }^{457}$

The most important indication for bloodletting at the most accessible place, which was usually the elbow, were acute fevers. It was equally called for in the case of a pestilential fever or a tertian fever. ${ }^{458}$ If the bloodletting could not be carried out, for example due to the age or poor condition of the patient, the disease was to be considered more dangerous. ${ }^{459}$ Also with illnesses such as melancholy, in which the morbid matter - in this case preternatural, burnt black or yellow bile or in rarer cases burnt blood - was located in the blood, an evacuation via an easily accessible vein seemed called for. ${ }^{460}$

Freeing the whole body of impure, superfluous, old, or clogged blood was also the goal of prophylactic bloodletting, which many people had done, especially in the springtime and fall, even if they were in good health. ${ }^{461}$ Emperor Ferdinand I, it appears, was bled twice a year, "cleansing" his body. ${ }^{462}$ The danger of an accumulation of impure humors was considered to be especially great in the winter, particularly as the sweat was not able to fully carry out its cleansing function. For this reason, it made sense to begin the winter with a "cleansed" body and to empty the body of accumulated waste matter by the end of winter.

If the physician deemed that the morbid matter had accumulated either primarily or exclusively in a particular place in the body, then it was important to draw the blood from a vein that, thanks to its location, allowed the morbid matter in question to be targeted specifically. In the case of a liver or spleen obstruction, the right and respectively the left vena salvatella was considered the best option. ${ }^{463}$ Letting blood from the vena cephalica, the vein between the thumb and

456 Cod. 11183 , fol. 87 r.

457 Cod. 11205 , fol. $414 \mathrm{v}$.

458 E.g. Cod. 11183, fol. 47v (pestilentlial fever), fol. 139v, fol. 294v (cases of febris continua) and fol. 410v (febris tertiana).

459 Ibid., fol. 345r.

460 Ibid., fol. 389v.

461 E.g. Cod. 11205, fol. 234v, "solet in vere mittere sanguinem"; Handsch mentioned this especially when patients had neglected a habitual preventive bloodletting and thus presumably promoted the development or progression of their disease (z.B. Cod. 11183, fol. 46v, fol. 122r and fol. 449v, "neglexit").

462 Cod. 11206, fol. 25v.

463 Cod. 11183, fol. 403r. 
forefinger was, as the name suggests, particularly indicated for diseases of the head (Greek: kephalos). ${ }^{464}$ Alternatively, one could open a vein on the head itself, at the forehead ${ }^{465}$ for example, in the nose, ${ }^{466}$ or under the tongue. ${ }^{467}$

The vena saphena on the leg, as Handsch learned, was often cut ("inciditur") so as to drain withheld menstrual blood. In German, this vein was also known as the "Frauenader", i.e. the "women's vein". ${ }^{468}$ Johann Neefe advised the sick Baroness of Hungerkasten to have blood let from her vena saphena three days before she expected her period. ${ }^{469}$ Mattioli tended to prescribe such bloodlettings to women in childbed. ${ }^{470}$ Handsch had heard from a barber-surgeon that most women even had the "women's vein" opened on both legs on a regular basis. ${ }^{471}$ Letting blood from the legs was indicated for diseases of the lower body and for uterine complaints in particular. ${ }^{472}$

Bloodletting did not only serve to rid the body of superfluous blood and morbid matter. A second important and widespread indication was the so-called revulsio. Here, bloodletting was used to give the movement of the morbid matter a different direction, to deflect it from its path towards the seat of the disease. A revulsio was thus advisable in cases of a local inflammation especially, as well as other pathological processes like podagra, ${ }^{473}$ where harmfully excessive quantities of pathological blood or more or less specific morbid matter were flowing to a certain body part. When Collinus's wife was suffering from an intense attack of podagra in her left foot, Handsch thus thought the correct countermeasure was to let blood from her left arm. ${ }^{474}$ The idea behind this was that if he had let blood from the foot instead so as to draw the morbid matter out of the body, this would have only pulled more morbid matter into the foot. When his teacher Lehner was suffering from arthritis in his left arm, he similarly had blood let from his right arm. ${ }^{475}$ For patients with strong nosebleeds or who were coughing up blood, letting blood

464 Ibid., fol. 46v and fol. 67r; Cod. 11210, fol. 56v.

465 Cod. 11183, fol. 123r, in the case of a "lethargicus"; Cod. 11205, fol. 234v and fol. 237r, on hemiplegia.

466 Cod. 11205, fol. 237r.

467 Ibid., fol. 483 r.

468 Ibid., fol. 450r.

469 Ibid., fol. 473r, "tribus diebus ante periodum".

470 Cod. 11183, fol. 138r.

471 Cod. 11205 , fol. $473 \mathrm{v}$.

472 Cod. 11210, fol. 56v.

473 Cod. 11207 , fol. 22 r.

474 Cod. 11205, fol. 306r-v; however, Handsch later read in Leonellus that bloodletting was indicated on the opposite side (ibid.).

475 Ibid., fol. 306v. 
from the leg was thought to lessen the rush of blood to the nose and lungs. ${ }^{476}$ In the case of a man with painfully swollen testicles, Gallo prescribed bloodletting at the arm. ${ }^{477}$

The decision was not always an easy one. Handsch and Mattioli both agreed that in the case of an apostema - an accumulation of pathological matter - of the liver, bloodletting at the opposite side, at the left arm, was indicated. With this they wanted to halt the influx of matter to the apostema, and they were acting on the authority of Avicenna and Jacques Despars (1380-1458). Their colleagues were of a different opinion, however. With reference to Galen and various more recent authorities, they explained that at the beginning, when the matter was still in motion, one should, just as one did with pleurisy, let blood from the affected side, thus drawing it to the outside. ${ }^{478}$

Physicians turned to a principle much like that of revulsio when they prescribed bloodletting in the case of obstructions of the vessels or organs. Their aim here was to get the stagnating, "obstructed" blood back in motion. ${ }^{479}$ Even in the case of Gregorius, who was emaciated and haggard and showing the first signs of dropsy, Gallo prescribed bloodletting due to the strong obstruction. ${ }^{480}$

As with purgatives, physicians sometimes refrained from bloodletting so as not to disrupt the work of nature herself. With red murrain, or when a rash appeared on the skin in the course of the French disease or other illnesses, this indicated that nature was successfully pushing the morbid matter to the periphery, ultimately discharging it through the open pustules. If, in such cases, one attempted to evacuate the morbid matter through bloodletting, one ran the risk of pulling the matter from the surface of the body back inside. ${ }^{481}$ For women, having blood let from the arm could disrupt the flow of menstrual blood to the uterus and thus impede health-preserving menstruation; this was because the menstrual blood would be directed upward instead of downward, as it was when blood was let from the vena saphena. ${ }^{482}$

In the case of injuries, bloodletting was controversial because of its weakening effect but Mattioli tended to see the positive sides. When there were

476 Cod. 11183, fol. 294r; Cod. 11205, fol. 168v.

477 Cod. 11207, fol. 206r.

478 Cod. 11183 , fol. $188 \mathrm{v}$

479 Cod. 11207 , fol. $213 \mathrm{v}$.

480 Ibid., fol. $213 \mathrm{v}$.

481 Cod. 11183, fol. 129v; Cod. 11207, fol. 13r and fol. 22r.

482 Cod. 11205, fol. 490v. 
injuries, especially head injuries, he would generally let blood unless there was considerable spontaneous bleeding already. His aim here was to limit the influx of blood and ward off the danger of inflammation. Handsch's colleague Tremenus held a similar view. ${ }^{483}$

Physicians regularly administered purgatives before bloodletting - cassia or, as was common in Italy according to Handsch, cassia with hiera picra. ${ }^{484}$ Giving purgatives beforehand ran counter, as Handsch noted himself, to the recommendations of Galen and Leonhard Fuchs, who advocated for the opposite order of operations. But as Willenbroch explained, it nevertheless made sense to first clean the bowels because otherwise the bloodletting might draw excremental matter from the intestines into the blood. ${ }^{485}$ In the case of complex disease patterns, a whole series of such evacuating measures could find application. In 1565, Handsch and Mattioli visited a woman who had been suffering for years. She described her complaints as follows: "It begins in the left side, then it goes to the stomach, then to the head, and sometimes in front of the eyes." 486 It sometimes seemed to her as if she were looking through a veil. She furthermore had lower back pain and her menstrual period was disrupted. Mattioli first gave her remedies such as fumewort and chicory to clean the blood. This was followed by bloodletting at the arm. After that she took a purgative, and then her blood was let from the vena saphena. At the end, she was also given sarsaparilla because it was suspected that her husband might have "infected" her. They were evidently referring to the French disease. ${ }^{487}$

In the vast majority of cases, a barber was entrusted with bloodletting. The wide-spread assumption in historical research has so far been that physicians avoided such manual tasks as a matter of principle. However, phrases such as "I cut", I "let his blood" ("misi ei sanguinem"), "we extracted" ("extraximus"), and "we cut" ("secuimus"), are found time and again in Handsch's notes, and they suggest that physicians may have in fact performed bloodletting themselves sometimes. ${ }^{488}$ In Hiob Finzel's practice journal too, we find expressions

483 Cod. 11207, fol. 161r; Handsch mentioned again a certain Tremenus; probably referring to Dr. Ludovicus Tremenus of Trent (Tovazzi, Familiarum (2006), p. 208).

484 Cod. 11205, fol. 485v.

485 Ibid.

486 Cod. 11183, fol. 215r, "In der lincken Seiten hebts an, von dannen kompt es umb den Magen, darnach ins Haupt, bißweilen vor die Augen”.

487 Ibid., "infectam esse a marito".

488 E.g. Cod. 11183, fol. 453r. This could still refer to the mere prescription of bloodletting. However, it is striking that these passages tend to refer particularly to patients from the doctor's immediate family or circle of friends; e.g. Cod. 11205, fol. 306r, on the sick wife of 
such as "I cut the [vena] saphena" ("incidi saphenam"), which suggest active involvement on the part of the physician. ${ }^{489}$

The amount of blood that was let was quite modest in most cases. Usually, physicians were content with three to four or, at most, six or seven ounces, less than a pint in other words. ${ }^{490}$ When a small vein was opened, the amount that was let was necessarily small. Only exceptionally, in the case of acute fevers for example, or serious mania and melancholy, did physicians see it fit to let so much blood that the sick person would faint. ${ }^{491}$ In such cases the physician was well-advised to feel the pulse and to stop the bloodletting before there might be fatal consequences. ${ }^{492}$

When using smaller veins, one generally had to keep the hand or foot in question in warm water so that the blood would continue to flow. In this situation, the passing of a certain amount of time could serve as the measuring stick instead of a volume of blood. Handsch observed that a barber let blood from a hand vein for as long as it took to say three Lord's Prayers, and then he bandaged the hand. ${ }^{493}$ He had heard that in Spain, blood was even let in a series of shorter sessions. The bloodletting was interrupted and not resumed until a few hours later. ${ }^{494}$

Bloodletting required skill and practice. In German the expression "die Ader schlagen" (to "hit" or "strike" the vessel) was used with respect to what was done to the vein, and with good reason. For a long time, it was to be understood literally. The bloodletter would take a so-called fleam, a sharp blade attached to a shaft, and set it down on the vein. He would then strike the fleam with his hand, opening the vein. However, Handsch generally wrote (in Latin) of "cutting" or "cutting into" the vein and mentioned as the tool a "phlebotomus", i.e. literally a vessel cutter. In contemporary sources we also find the term "flebotomator" for the bloodletter. ${ }^{495}$ This suggests that during his time the veins were usually opened with a knife or a lancet, as we can also see in some contemporary visual representations.

Collinus, "misi ei sanguinem ex mediana"; Cod. 11206, fol. 43v, "D. Matthiolus secuit mihi venam in manu."

489 Ratsbibliothek Zwickau, Ms. QQQQ1b, p. 541.

490 Benedetto Vittore also usually ordered that from three to seven ounces be let (Biblioteca comunale Aurelio Saffi, Forlì, Fondo antico, Ms. 94, fol. 17r).

491 Cod. 11183, 389v, on the cantor Matthias who suffered from the disease melancholia; Cod. 11210, fol. 55v; Cod. 11226, fol. 79v; in the case of the melancholic Fasbinder, however, a pound of blood was deemed enough (Cod. 11183, fol. 426v).

492 Cod. 11210, fol. 55v.

493 Cod. 11183, fol. 87v.

494 Ibid., fol. 449r.

495 Biblioteca comunale Aurelio Saffi, Forlì, Fondo antico, Ms. 94, fol. 17r. 
When letting blood from the arm veins, the procedure was comparatively simple. Very corpulent patients whose veins were hardly recognizable could present a challenge, however. While with Bellocati in Trento, Handsch saw how his teacher got his patient, a very corpulent monk, to hold a heavy weight in his hand so that the vein would protrude better. ${ }^{496}$ Handsch also learned from the barber-surgeon Melchior that in the case of "fat bodies", like that of the Archduke, one should use a wide bloodletting knife. ${ }^{497}$ Other veins were not easy to find and to strike even if the person was not corpulent. This was especially true of the veins at the back of the hand. ${ }^{498}$ When, for example, a physician prescribed bloodletting at the vena salvatella, the patient was usually asked to put his or her hand in warm water, so that the vein could be found in the first place. ${ }^{499}$ As Handsch knew from a barber, it was not easy to strike the vein without accidentally injuring the bone beneath it, ${ }^{500}$ and this was not to mention the danger of hitting a nearby artery. It was especially difficult to let blood from the vein at the hollow of the knee, the vena poplitea. In some cases, bloodletting at that location could be very useful, as Handsch learned as a student. Falloppia explained to his students, however, that he had never seen the vena poplitea struck. Oddo Oddi claimed he had seen this done on a very thin woman. Bellocati had supposedly "cut" it once on a Greek man. ${ }^{501}$ Willenbroch wanted to have this so-called "crural vein" opened on a patient suffering from uterine complaints and sand in her urine. The vein, however, could not be located even in warm water, so he had to make do with letting blood from the ankle vein. ${ }^{502}$

Even with comparatively accessible veins, barber-surgeons failed sometimes. They could not find the vein, ${ }^{503}$ or it took them several attempts before they successfully struck it. In the case of the young wife of a very old nobleman, for example, the barber tried four or five times to no avail before opening the arm vein. ${ }^{504}$ Of course, bloodletting necessarily left behind a small wound that needed to be bandaged well ${ }^{505}$ and which took some time to heal. Some patients had a blue arm after the procedure..$^{506}$

496 Cod. 11183, fol. 409v.

497 Ibid., fol. $444 \mathrm{r}$ and fol. $446 \mathrm{r}$.

498 E.g. ibid., fol. 398v, on the thumb vein.

499 Ibid., fol. 46v and fol. 441r; Cod. 11240, fol. 127r.

500 Ibid., fol. 87v.

501 Cod. 11210, fol. 158v, "secuit”.

502 Cod. 11183, fol. 351v.

503 Ibid., fol. 137r.

504 Cod. 11205, fol. 234v.

505 Cod. 11183, fol. 84r.

506 Ibid., fol. 333r. 
Understandably, some patients awaited bloodletting with a certain amount of trepidation. The Count of Schimmern took a mouthful of strong wine to help him face his fear and the looming possibility of falling unconscious. ${ }^{507}$ To prevent fainting, Mattioli recommended pomegranates ${ }^{508}$ and he had Philippine Welser suck on cloves. Fearing that she would faint, Katharina von Loxan kept galangal in her mouth. ${ }^{509}$ Handsch noted that, as a rule, it was a good idea for patients to lie in bed for a while after bloodletting to prevent fainting. ${ }^{510}$ After having had only a good four ounces of blood let, "everything went green and yellow for Frau von Heidenreich". ${ }^{511}$ And some patients actually did lose consciousness. In this case, one was to put them in a reclining position and moisten their face with vinegar and Malvasia wine..$^{512}$

Bloodletting was an unpleasant and painful procedure. Nevertheless, many patients demanded it of their own accord. They believed they knew of its beneficial effects from their personal experience. Anna Gramoserin, for example, found that bloodletting at least temporarily helped with her troubled menstruation. ${ }^{513}$ Some even felt immediately better after bloodletting. The intense abdominal pain of a patient called Tucher, for example, was initially treated with clysters, but to no avail. When his blood was let, however, the pain immediately vanished..$^{514}$

Cupping was somewhat less painful. For dry or bloodless cupping, cupping glasses were warmed and placed on the skin. Handsch's stepmother called them "blind heads". ${ }^{515}$ As the glass cooled, it pulled the surface of the skin inside it. One could also use, as was common in Italy according to Handsch, particularly large cupping glasses, putting burning hemp or tow ("stuppa") into them. The flame would consume the air inside the glass and the resulting "vacuum", as Handsch called it, would pull the skin into the glass with great force. It was furthermore helpful if the cupping glass had a small hole on the other side which could be sealed with wax. When one wanted to take the cupping glass off the skin, all one had to do was remove the wax. Then air would flow into the glass and it could be taken away without the use of force..$^{516}$

507 Ibid., fol. 470r.

508 Ibid., fol. 444r.

509 Ibid., fol. 411r.

510 Ibid., fol. 409v.

511 Ibid., fol. 393r.

512 Ibid., fol. 473v; ibid., fol. 479r.

513 Cod. 11207, fol. 225r-v, letter from Anna Gramoserin to a "Frau Doctorin", probably to the wife of Andrea Gallo, 19 August 1550.

514 Cod. 11183, fol. 156r.

515 Cod. 11205, fol. 472v.

516 Cod. 11210, fol. 61r, note added in the margins. 
This bloodless kind of cupping, which pulled fluids in the body in the direction of the glass, could be enough in the experience of medical professionals to stop a nosebleed or to suppress menstruation if this were desired. ${ }^{517}$ In other cases, for example with phlegmons and hardened tumors, and with agonizing local pain or tension, bloody cupping was indicated. Here, one incised the surface of the skin before applying the cupping glass. In Italy knives were used to this end. ${ }^{518}$ Later, so-called scarificators were desigend, small devices with a spring mechanism and several small blades which, operating simultaneously, would scarify the skin. When the skin was pulled into the cooling glass, liquid came out. According to Arnaud von Villanova, wet cupping could serve as an alternative to bloodletting if the patient was in a weakened condition or was shying away from having his or her blood let. ${ }^{519}$ If the skin was cut into in such a way that blood flowed visibly, however, a considerable amount of blood could be taken in this way as well. In the case of a terminally ill archivist ("chartarius"), in Prague, the physicians had to forgo cupping because the sick man said he already had little blood. ${ }^{520}$ The rather corpulent Archduke, on the other hand, once had ten cupping glasses applied. His physicians then weighed the blood and arrived at thirteen ounces - an average of more than an ounce per glass. ${ }^{521}$

Instead of wet cupping with a cupping glass, one could also use leeches, applying them to the anus or behind the ear for example, so that they would attach and fill with blood. Handsch only mentioned them peripherally ${ }^{522}$ and above all during his time in Italy. ${ }^{523}$ There he also observed that they were kept in glass vessels filled with water at the apothecary's. ${ }^{524}$ Maybe their use was more common south of the Alps. Benedetto Vittore in Bologna, for example, frequently recommended their use, behind the ears or on the hemorrhoidal veins, where they would draw three to four ounces of blood. ${ }^{525}$

517 Ibid., foll. 60v-61r.

518 Cod. 11240, fol. 35v.

519 Cod. 11210, fol. 61r.

520 Cod. 11183, fol. 121v.

521 Ibid., fol. 446r.

522 Cod. 11210, fol. 61r.

523 Cod. 11226, fol. 40v; Cod. 11238, fol. 107r.

524 Cod. 11240, fol. 2v; Cod. 11210, fol. 139r.

525 Biblioteca comunale Aurelio Saffi, Forlì, Fondo antico, Ms. 94, fol. IIr, fol. 5r, fol. 6r, fol. 39r, fol. 43r, fol. 88r, fol. 100r and fol. 106r. 
Bloodletting and wet cupping inevitably robbed the body of valuable natural blood and weakened it in its battle against the disease. Gallo warned that he who had his blood let often would age more quickly. ${ }^{526}$ "Blood is the treasure of life and the favorite son of nature", Handsch wrote, repeating an Avicennian adage. ${ }^{527}$ In another place, he noted, "He who diminishes the blood, diminishes life". ${ }^{528}$ It was thus highly advisable for physicians to carefully consider whether the letting of blood was indeed indicated and necessary. They also had to take the patient's physical constitution into account and adapt the amount of let blood to the patient's general health. With sanguine, blood-rich patients, one could take a relatively ample amount. ${ }^{529}$ Weakened patients, however, were only to have a small quantity let or to only have it let in small increments, ${ }^{530}$ and sometimes it was best to forgo the procedure altogether. ${ }^{531}$

One had to be especially cautious with children. Handsch noted in several entries that it was best not to let the blood of children until they had reached the age of ten or even fourteen. ${ }^{532}$ While it was true, Handsch wrote, that Averroes told of a plague-stricken three-year-old boy who was freed of the disease because his blood was let, one swallow did not make a summer. ${ }^{53}$ At the same time, it was observed that children sometimes suffered bleeding wounds, and thus it was known that they would not necessarily be unduly weakened by a loss of blood. ${ }^{534}$ As Handsch observed, even when the umbilical cord of a newborn had not been properly tied by the midwife, leaving the linens covered in blood the next day, the child survived. ${ }^{535}$

As a rule, it was also best not to perform bloodletting and wet cupping on old people. ${ }^{536}$ Here too, the person's physical constitution had to be considered. If he or she had a strong constitution and a sanguine temperament, bloodletting could

526 Cod. 11207, fol. 197v.

527 Cod. 11205, fol. 398r.

528 Cod. 11204, fol. 45v: "Qui minuit sanguinem, minuit vitam."

529 However, despite his phlegmatic temperament, Ulrich Lehner also often underwent bloodletting on his arm or foot, and with good success, as he reported. He also was cupped every fortnight (Cod. 11205, fol. 235v).

530 Cod. 11210, fol. 55v.

531 Cod. 11207, fol. 51r; Cod. 11238, fol. 106v.

532 Cod. 11240, fol. 6v.

533 Cod. 11210, fol. 55r.

534 Cod. 11240, fol. 6v.

535 Cod. 11205, fol. 238v.

536 Ibid., fol. 113v. 
be indicated even at an advanced age; experience taught that some seventy-yearolds tolerated it better than the odd sixty-year-old. ${ }^{537}$ Aside from this, further factors were to be taken into consideration as they were with other treatments: the season (spring was best), the person's way of life, and even - as with prophylactic bloodletting - the time of day (preferably the morning). ${ }^{538}$

\section{Cauterization}

A particularly invasive and rather painful means by which morbid matter could be guided away from the site of disease and evacuated was the deliberate creation of an ulcer by means of cauterization. In the case of the socalled cauterium actuale this was done by means of glowing hot iron which burnt a hole into the skin and created an ulcer. A somewhat milder approach was the cauterium potentiale. ${ }^{539}$ Here, the artificial ulcer was created by means of caustic substance that was applied to the skin. The ulcer would then be kept from closing by inserting foreign matter such as a little ball made of wax or silver into it. In this way, an ongoing efflux of oozing matter would be maintained. As Gabrielle Falloppia explained to his students, using a hot iron was in many ways safer because the effect of causic substances on the skin could not easily be controlled. In everyday practice, however, physicians mostly used a cauterium potentiale, to please their patients and also because "effeminate" patients abhorred the sight of fire. $^{540}$

As in the case of blood-letting the choice of the site where the ulcer or "fontanella" was created could reflect two basic types of rationale. One could either cauterize close to the area where the morbid matter was thought to have accumulated and thus divert the flow and promote its direct evacuation, for example, through an ulcer on the arm when the chest was affected. Or one could use the cauter in order to direct the flow of morbid humor away from the affected part. In the case of a chest disease this could mean cauterizing a leg. ${ }^{541} \mathrm{~A}$ further

537 Cod. 11210, fol. 55r.

538 Ibid., foll. 55v-56r.

539 Biblioteca comunale Aurelio Saffi, Forlì, Fondo antico, Ms. 94, fol. 99r-v.

540 Falloppia, De cauteriis (1570), fol. 71v.

541 In his detailed discussion of the cauterization, Girolamo Capivaccia added the interceptio as a third type of rationale to derivatio and revulsio. Here the aim was to intercept the flow of peccant humor to the affected site, e.g., when humor that descended from the head into the spine was evacuated by means of an articifial ulcer in the neck (Girolamo Capivaccia, De recta cauteriorum administratione, in: Scholz, Consiliorum medicinalium (1598), coll. 1158-1164). 
use outlined by Falloppia was to dry and strengthen the very limb itself which was cauterized; it seems to have played a very minor role in ordinary medical practice, however. ${ }^{542}$

Handsch rarely refers to patients explicitly on whom cauterization was performed. He seems to have perceived cauterization as a treatment mostly for particularly serious cases. He does mention, however, that Gallo used it quite often. ${ }^{543}$ In Padua, Falloppia and his fellow professors frequently recommended or at least discussed it when they offered their judgment on individual cases in a collegium. ${ }^{544}$ We find the same in the practice of Benedetto Vittore in 1540s-Bologna who even convinced patients from the highest ranks of society to subject themselves to the painful procedure. ${ }^{545}$ More resarch is needed to assess whether the procedure was more widely used in Italy than north of the Alps.

\section{Sweating}

As we have seen, visible sweat as well as perspiratio insensibilis, invisible evaporation through the pores of the skin, counted among the most important excretions in the medicine of the Renaissance period. In the healthy person, sweat served to evacuate the non-assimilated leftovers of the third concoction, which took place in the individual body parts. When a person was ill, sweat freed the body of liquid and volatile morbid matter. As the ancient Hippocratics had already observed, it was a good sign when, during acute illness, a sweat broke out on the so-called "critical" days of a disease, thereby freeing the body of morbid matter and ending the fever. ${ }^{546}$ Consequently, physicians were well advised to stimulate excretion via the skin if a harmful, pathological humor inside the body was stirring up trouble, as with fevers and very much in the case of pestilential fevers. ${ }^{547}$ Of course they he had to ensure, as with bloodletting, that the flow of perspiration did not weaken the patient too much. ${ }^{548}$ There were different ways to open the pores and increase perspiration. One could use warm compresses or warm lavations, rub the skin with a warm, rough linen cloth or

542 Falloppia, De cauteriis (1570), fol. 71v.

543 Cod. 11240, fol. 36v.

544 E.g. Trincavella, Consilia (1587), col. 22, col. 197 and col. 263,

545 Biblioteca comunale Aurelio Saffi, Forlì, Fondo antico, Ms. 94, fol. 5v, fol. 80r, fol. 81r, fol. 83r-v, fol. 99r-v, and fol. 106v.

546 Cod. 11210, fol. 63r.

547 Ibid., fol. 62v.

548 Ibid., fol. 63r. 
have the patient lie in a previously warmed bed; one could wrap the patients in warm cloths and/or put warm bricks at their feet. ${ }^{549}$ One could also rub warm ointments on the skin and thus not only widen the pores but heat up the humors themselves. ${ }^{550}$ Sometimes physicians even ordered the patient's hair be cut so that the harmful vapors could escape better, ${ }^{551}$ or they prescribed sweatinducing medications, so-called sudorifica.

Requiring more preparation and work were the widespread steam baths and sudatories. We will be returning to these when we discuss bathhouses, but according to Handsch, they could also be set up in the patient's house. One had to put the sick person on a ladder over a bathtub that was filled with hot stones and then pour water over the stones. "Hot" and "moist" herbs could be decocted in this water beforehand. The patient's body and the bathtub were to be wrapped in linens, while only the head was to be left exposed, covered merely with a hat, so that the vital force ("virtus vitalis") would not be weakened due to the excessive heat and the flow of perspiration. ${ }^{552}$

\section{Thermal Springs and Healing Waters}

Another important means to cleanse not only the outside but also the inside of the body was bathing in the waters or drinking the water from a spring that was known for its curative virtues. In this sense, Handsch's friend Mitis, for example praised the thermal springs in Teplitz, saying, "The water washes away all the harmful humors of the sick and suffering body". ${ }^{553}$ Visiting thermal springs and drinking healing water became increasingly popular in the late Middle Ages and the Renaissance, first in Italy and soon also north of the Alps.

Different thermal springs were distinguished from one another on the basis of the kind of water they had and what each was indicated for. As Handsch's detailed notes make clear, it was expected of the learned physician that he understand which water or spring was suitable and proven for which illness, just as he was to prescribe specific medications for specific ailments. Salty or nitrous springs were said to be good for arthritis, palsy or paralysis, asthma and dropsy. ${ }^{554}$ Sulfurous water softened and warmed the nerves and also helped with skin complaints of all

549 Ibid., foll. 62v-63r.

550 Ibid., fol. $63 \mathrm{v}$.

551 Cod. 11205 , fol. $584 \mathrm{v}$.

552 Cod. 11210, fol. 62r-v.

553 Cit. in Guth, Idyll (1930), p. 163.

554 Cod. 11210, fol. 61v. 
kinds, indurations of the spleen and liver, podagra and uterine complaints. ${ }^{555}$ Ferrous water could be used for the stomach and the spleen. Handsch also listed thermal springs that were "aluminosae" - presumably containing alum - pitchy or tarry ("bituminosae"), ore-bearing or cupriferous ("aereae", "cupreae") or which contained gold, as well as their respective indications. ${ }^{556}$

The area around Padua was famous for its thermal springs. Handsch's teacher Falloppia devoted large parts of a lecture series to the chymical composition of the various waters and to their beneficial effects in specific diseases. ${ }^{557}$ Of the healing baths in Tyrol, the Heiligenkreuz bath near Hall was thought to be beneficial for swellings in the abdominal area or legs, or as a treatment for emaciation. The water in Sellrain was recommended as a treatment for uterine illnesses in particular, especially if the uterus was "contaminated" ("inquinata") as when there was white discharge. The water of the nearby Teffelsbad, on the other hand, had astringent properties according to Handsch and could be recommended as a treatment for hemorrhoids, wounds, and ulcers. ${ }^{558}$

As Handsch took from a consultation letter written by Johann Neefe, it was always important to bear the patient's strength in mind and not overburden him. Accordingly, baths lasting four to five hours were generally sufficient. As for drinking water in the baths, Handsch had already learned in Padua ${ }^{559}$ that the amount imbibed should be gradually increased until an upper limit was reached that was still well tolerated and "the water, without causing complaints, had made the person produce five, six, or seven stools". 560

Handsch later accompanied Ferdinand II, Philippine, and other members of the court to the healing baths in Karlsbad twice, once in 1571 and again in $1574 .{ }^{561}$ The princely couple bathed for hours in the thermal springs there and underwent lengthy ablutions. Not only this, they also drank incrementally higher quantities of the water. Even Philippine, in the course of her six-week stay, drank as many as eight seidels a day- approximately four liters ${ }^{562}$ - and she also took purgatives.

555 Ibid.

556 Ibid.

557 Falloppia, De medicatis aquis (1564).

558 Cod. 11183, fol. 459r.

559 Cod. 11205 , fol. 568v.

560 Cod. 11204, foll. 14r-15r: "Ex Naevii regimine"; similarly Trincavella recommended that a noble patient of his - he did not give the name - gradually increase his daily intake (Trincavella, Consilia (1587), coll. 710-11).

561 Cod. 11204, foll. 1r-16v and foll. 28r-30v; Oberrauch, Medizin (2012), pp. 365-368; Stolberg, Krankheitsgeschehen (2021).

562 Cod. 11205, fol. 256v. 
Handsch documented the purifying effects: her plentiful urine, her bowel movements numbering as many as seventeen per day, her perspiration, and at the end the painful rashes on her arms that resembled erysipelas. ${ }^{563}$ In 1574, Ferdinand began treatment in Karlsbad and then went on to Pürglitz, where he drank water from the thermal springs of Lucca. Here, we see indications of the beginnings of a trade in mineral or healing water, because the water was brought to Bohemia from Italy. ${ }^{564}$ He increased the quantity from six pounds or nine cups per day to twelve, then eighteen cups, and went on to a maximum of twenty cups a day. ${ }^{565}$ The water produced the desired effect, in Handsch's words: "He made much sweat, stool, and water" ("multum sudavit, cacavit et minxit"). Ferdinand felt better, even if by the end he complained that the water was attacking his stomach. ${ }^{566}$

\section{Dietetics: Eating, Way of Life, Emotions, and Sexuality}

Another important pillar of medical treatment was dietetics, the branch of knowledge concerned with the maintenance of health through diet and way of life. Significant attention was devoted to it in contemporary medical literature. In the course of the early modern period, there was a flood of publications on dietetic questions. This literature has garnered considerable attention in recent historical research. Valuable overviews have been given by Sandra Cavallo and Tessa Storey, David Gentilcore, Heikki Mikkeli, and Andrew Wear. ${ }^{567}$

The wealth of extant printed dietetic guidebooks can mislead us, however, into overestimating the significance of dietetics in the lives of ordinary people. While the sheer number of publications concerning health that were brought out in the sixteenth and seventeenth centuries as well as the numerous editions of bestsellers like Alvise Cornaro's De vita sobria ${ }^{568}$ do allow us to conclude that the printers and publishers had put their finger on a profitable market, the degree to which these works were actually read is another matter. The copies of health guidebooks that have survived show few signs of wear or use, suggesting that many readers tended to search for rather specific information on specific illnesses or pertaining to specific questions, and left large portions of these publications

563 Cod. 11204, foll. 1r-4v.

564 Ibid., fol. 29r.

565 Ibid.

566 Ibid.

567 Mikkeli, Hygiene (1999); Wear, Knowledge (2000), pp. 154-209; Cavallo/Storey, Healthy living (2014); Gentilcore, Food (2006).

568 Cornaro, Discorsi (1627). 
unread. ${ }^{569}$ We must certainly not assume without further investigation that the dietetic directives were applied in practice. It is possible that such books or booklets gave many readers a sense of security, a trust that illnesses were preventable and controllable should this become necessary down the road.

The interest in dietetic advice appears to have been significantly greater when someone fell ill, especially among the upper classes. After all, dietetics was not only supposed to ward off disease in healthy times; since antiquity, it had been an important component of therapy. Much like the various evacuant and strengthening remedies, dietetics was to support nature in her battle against the disease. Handsch even gave an account of an old patient with jaundice who was dissatisfied with his previous physician because this physician had not given him any dietetic advice. ${ }^{570}$

In both the prevention and treatment of disease, early modern dietetics was based in large part on the ancient teaching of the res non naturales. Some authors, with Hippocrates as a model, distinguished five external influences which came from a person's way of life, acted on the body, and could give rise to diseases: eating, drinking, sleeping, movement, and sexuality. ${ }^{571}$ Most sixteenth-century writers of health guidebooks and consultation letters for individual patients drew on the traditional Galenic six-point scheme, however. Here, eating and drinking were conflated and three further aspects were added: the air, the passions, and excretions over which were largely beyond control, however.

Most people were simply at the mercy of the local air and its influence. Very few were able to move somewhere else for health reasons. At most, one could avoid leaving the house if the air seemed especially hazardous or insalubrious, for example during a plague or in the damp, cold winter months. Or one could try to clean the air with fire or with aromatic substances and to condition the air within the living quarters depending on a person's disease and complexio. If someone had a hot and dry illness, for example, one could sprinkle liquids on the floor and lay out wet flowers. ${ }^{572}$

When it came to the affects of the mind, the passions or emotions, the mantra was again moderation. Anger, in particular, had to be held in check while positive emotions like temperate joy, especially through pleasant conversation or beautiful music, would promote health. This kind of advice could be seen as an attempt to promote the process of civilization, encouraging people to tame their emotions for their own good if not of that of others. But it remains highly

569 Stolberg, Negotiating (2004); Richards, Useful books (2012).

570 Cod. 11205, fol. 574r: "Non placet M. Jacobus [Camenicenus, M.S.] ei, quia non praescripsit diaetam".

571 Mikkeli, Hygiene (1999), p. 57 and pp. 71f.

572 Cod. 11210, fol. 43v. 
questionable whether people in the sixteenth century actually worked harder to control their emotions for health reasons. In the letters the sick and their families wrote to distant physicians asking them for epistolary advice based on a detail account of their disease, it is only from the eighteenth century onwards that I have found personal testimonies which show that people indeed worked to keep their feelings from others, for example when affronted or after losing a game and feeling disappointed. And tellingly the reason they mentioned this was not to underline their ability to control their emotions for the purpose of promoting health but quite the contrary: they believed that the suppressed emotion had had a lasting harmful effect on their health. ${ }^{573}$

More human control was possible when it came to sleep, exercise and rest. Moderate movement was considered healthy. But, of course, one was not to overdo it, because here too, as Hippocrates had written, every "too much" was harmful. ${ }^{574}$ Sleep had to be long enough to allow sufficient time for concoction, but not so long that the subsequent excretion would be hindered. As a rule, this was seven to eight hours. ${ }^{575}$ Sleep position could have a beneficial or detrimental effect on the concoction processes during the nighttime. It was best, Handsch learned, to fall asleep while lying on one's right side, so that food could easily enter the stomach, and then to roll over to the left side so as to encourage the subsequent concoction in the liver. ${ }^{576}$ It was dangerous, however, to sleep on one's back, which could cause nightmares, apoplexy, paralysis, and other problems because the intestines in this position pressed on the vena cava. ${ }^{577}$

The medical literature was more ambivalent about sleep during the day. As Handsch learned, Hippocrates and Aëtius of Amida, proclaimed it harmful unless one had slept poorly or not at all the previous night or if the senses were weary. ${ }^{578}$ This was because the brain filled with too much fluid during daytime sleep, which caused heaviness of the head ("gravedines capitis") and made the head susceptible to "cold" illnesses. ${ }^{579}$ It was better therefore to go for a walk after eating and relax the mind. ${ }^{580}$ Handsch explicitly advised the old, jaundiced man mentioned above against napping. ${ }^{581}$

573 Stolberg, Emotions (2019).

574 Cod. 11210, fol. 50v.

575 Ibid., fol. $52 \mathrm{v}$.

576 Ibid.

577 Ibid., fol. 53r.

578 Ibid., fol. 52 r.

579 Ibid., fol. 52v.

580 Ibid., fol. 52r, "animi aliqua laxamenta adhibenda"; the work of Aëtius of Amida (Aëtius, Libri XVI (1535)) was widely read and quoted in the sixteenth century.

581 Cod. 11205, fol. 574r. 
The possibilities of active self-regulation were greatest with respect to nutrition and diet. In the health guidebooks as well as in the consultation letters to individual patients, this topic was often given by far the greatest amount of consideration. The greatest challenge here was adapting the diet to the patient's temperament, age, sex, individual constitution, and way of life. ${ }^{582}$ The predominant primary qualities of the food had to be appropriate. For one patient, a strong wine might have a strengthening effect, while for another it might be contraindicated because, in the case of a fever for example, it might increase the pathological heat. Eating habits also had to be taken into consideration. Foods the person commonly ate were preferable; if food that was out of the ordinary was given, it had to be introduced slowly and carefully. ${ }^{583}$ Favorite foods were also to be preferred if possible. Handsch noted that foods the patient ate with desire ("cum voluptate") were more readily accepted and concocted by the stomach. ${ }^{584}$ One was furthermore not to eat an unruly assortment of foods and it was important to choose the right time to eat. It was healthy to eat at the same times of day, when one's appetite was keen and after one had had some exercise and the previous meal had left the stomach. ${ }^{585}$ On the other hand, if a patient suffered from a fever attack and another illness involving paroxysms, it was better to wait until the attack had passed. ${ }^{586}$ Following the change of the seasons, it was better to eat warming and drying foods in the wet and cold winter, while in the spring, a more meat-rich diet was good. According to Hippocrates, a rich diet was always indicated in the winter and spring because the inner warmth was strong and concentrated and sleep was long. In the summer, one needed to eat less and to drink more, and cold dishes made sense. In the fall, more food was once again indicated and it was best if it were dry. ${ }^{587}$

The regimens physicians recommended for specific diseases in printed guidebooks and in their handwritten letter consultations for upper-class patients could be very detailed. They sometimes listed dozens if not hundreds of foods that were to be preferred or avoided. In the retrospective view, the minutiae of these dietetic directives can be interpreted as an expression of the efforts made by physicians to exhaustively medicalize everyday life in times of both sickness and health, to subject it to the dictates of medical expertise. At the same time, this was a platform for physicians to prove their abilities through meticulous instructions, to

582 Cod. 11210, foll. 44v-45r.

583 Ibid., fol. 45r.

584 Ibid.

585 Ibid.

586 Ibid., fol. 45v.

587 Ibid., foll. 44v-45r. 
show how they were able to tailor their prescriptions to their patients' individual constitutions.

Turning to the dietetic advice noted down by Handsch - advice either he or other physicians in his professional environment gave to patients in day-to-day practice - we find that it was far from excessive. It was limited to a few points which the patients and their relatives could retain after having merely listened to the physician, and it concerned nutrition above all. Handsch and his colleagues mainly advised against foods that were "difficult to digest", food that was cool and therefore increased mucus production, as well as foods that caused winds. In the case of fevers, they recommended that one avoid wine and other excessively "heating" foods and beverages. Accordingly, Handsch ordered some patients not to eat fish. ${ }^{588}$ And indeed one female patient confirmed that after eating fish she felt "heavy in the stomach" ${ }^{589}$ Handsch noted down the basic rule: "Fish is forbidden when there is a fever". Some people even came down with a fever after eating fish or suffered a relapse afterwards. ${ }^{590}$ Handsch also advised against peas, cabbage, old beer, and other flatulent foods and knew that he was in the company of many a good physician in doing so. ${ }^{591}$ He recommended, on the other hand "light fare" such as egg drop soup or chicken ${ }^{592}$ and, very frequently, toasted bread. ${ }^{593}$ Still today, zwieback or rusks are considered by many people to be particularly "digestible" and appropriate in the case of a fever. A brief comparison with Benedetto Vittore's treatment of his patients in Bologna in the 1540s yields a very similar result: Vittore often recommended some dietetic restrictions but usually his advice was very simple and limited to eating bread soup ("panatella"), broth or some mashed food and to drinking no or only little and watery wine. ${ }^{594}$

Within the res non naturales, the excretions were assigned a special status in the context of the Galenic six-point scheme. If excretion was disrupted, it was considered a crucial cause of illness. But excretion could only be indirectly influenced, and only to a limited extent insofar as one controlled the other res non naturales so as to promote health. This meant moderate exercise, spending time in warm places, and consuming food and drink that stimulated excretion (or inhibited it). There is a striking contrast between the prominent position of the excretions in theoretical discussions of the res non naturales and their

588 Cod. 11205, fol. 519v.

589 Ibid., fol. $514 \mathrm{v}$.

590 Ibid., fol. $396 \mathrm{v}$.

591 Ibid., fol. 396v, fol. 401v, fol. 514v and 574v.

592 Ibid., fol. $562 \mathrm{v}$.

593 E.g. ibid., fol. 519v.

594 Biblioteca comunale Aurelio Saffi, Forlì, Fondo antico, Ms. 94. 
marginal position in dietetic instructions or regimina for specific patients, even when the latter, following the widespread practice, dealt with all six res non naturales in turn.

There was one excretion, however, that in and of itself was largely subject to the human will and human control, namely the excretion of seed. Insofar as it was included in sexuality, this excretion was one of the five points in the Hippocratic five-point scheme. It was not assumed that one could have complete control over this excretion, as nocturnal emission was of course a known phenomenon. Handsch himself experienced it physically and patients described it as well. ${ }^{595}$ Furthermore, involuntary, uncontrolled genital discharge of the kind that we would today attribute to an infection, was taken then to be gonorrhoea in a literal sense, that is a "semen flux". However, as opposed to the excretion of feces and urine, which could at best be delayed somewhat, or menstrual bleeding, which was not at all subject to the woman's will, the discharge of semen was seen to be largely subject to the deliberate decision of the individual.

Although semen was considered a kind of excrement, it was one that was especially useful and valuable. According to Avicenna it was formed from the best, most delicate parts of the blood and, with man as with woman, was rich in spiritus, though more so with man. ${ }^{596}$ It could even be used to treat illnesses. Handsch heard from Gallo that a sick patient called Adrianus had been given male seed to drink by an old healing woman, and Handsch added that this advice was also found in the works of medical authors. ${ }^{597}$ He even believed he had found an indication in the Hippocratic Epidemics that semen could cure dysentery. Handsch read here that the slightly oily, temperate seed alleviated the acridity of the humors and combatted intestinal ulcers in the person who received it. He concluded that Hippocrates must have permitted anal intercourse. ${ }^{598}$

Far more than with other excretions, however, an excessive excretion of this valuable substance was fraught with danger in the perspective of this time, be it through marital intercourse, "unchastity", or masturbation. As Handsch took from his reading, the loss of seed weakened the senses and the body as a whole, accelerated aging, and damaged the eyes and head, the nerves, the joints, the chest, the kidneys, and the loins. ${ }^{599}$ In the consilia of Bartolomeo Montagnana, he read that excessive coitus was often the reason for an obstruction

595 Cod. 11183, fol. 142v; ibid., fol. 258v; Cod. 11205, foll. 172r-179r, copy of a letter from Christoph von Hassenstein.

596 Cod. 11210, fol. 9v.

597 Cod. 11207, fol. 43r.

598 Ibid., fol. 87r, "exercere venerem posticam”.

599 Cod. 11210, fol. 66v. 
of the liver. ${ }^{600}$ In Padua, he experienced how Trincavella traced the complaints of a young man to a weakness of the stomach that had arisen from "too much Venus" ${ }^{601}$ Handsch himself attributed the bladder ulcers of a male patient to "too much coitus". ${ }^{602}$ Laypeople as well were convinced and shared their subjective, bodily experience that the body was weakened following a loss of semen. An ailing Bohemian nobleman from the Prague court, for example, did not dare to have intercourse with a woman although he was forty and in the prime of his life, for fear that it would be detrimental to his health. ${ }^{603}$

Particularly at risk were aging and old people whose vital heat was already diminished. Thus, Lehner advised a patient who was complaining of impotence to avoid the pleasures of Venus entirely, given his age. It was more harmful, he claimed, to lose an ounce of semen than a seidel or a pound of blood. ${ }^{604}$ Handsch recalled Lehner's comment about an old tutor who could still have been alive in Lehner's opinion "had he not taken a young wife" ${ }^{605}$ And the severe colic of a certain Dr Andreas - he was presumably in the service of the Archduke at Ambras - was traced in part to his young wife, because too much coitus weakened the liver. ${ }^{606}$ In a book on the history of Bohemia, Handsch found an anecdote about the very old Emperor Maximilian to whom King Wenzel offered his young daughter in marriage. The emperor retorted that there was no better way to kill a man honestly than to give him a young woman as his wife. ${ }^{607}$

Regardless of age, frequent intercourse, it was believed, could also lead to a pathological loss of semen that was independent of sexual activity. Bellocati explained to his students that too much coitus weakened the seminal vessels and their capacity to hold the semen. The result was a pathological efflux of semen, a gonorrhoea. ${ }^{608}$ This was particularly true of masturbation, whose harmful effects on the genitals were thrown into relief by sixteenth- and seventeenthcentury authors. ${ }^{609}$ The French physician Louis Saporta, for example, attributed the gonorrhoea of a young man not to a profusion of semen, but rather considered it the result of a weakness and flaccidity of the seminal vessels, which the

600 Cod. 11205, fol. 219v.

601 Cod. 11238, foll. 109v-110r.

602 Cod. 11205, fol. 230r.

603 Ibid., fol. 102r.

604 Ibid., fol. 256v.

605 Ibid., fol. $256 \mathrm{v}$ and fol. $266 \mathrm{v}$.

606 Cod. 11183, fol. 313v.

607 Cod. 11205, fol. 257r.

608 Cod. 11238, fol. 131r and 133r.

609 Da Castro, Universa mulierum medicina (1662), p. 97; Ettmüller, Opera (1685), p. 422. Timaeus von Güldenklee, Responsa (1668), pp. 191-193. 
young man had brought upon himself in part by "frequently pulling back the foreskin followed by seminal discharge". 610

If, however, the semen was inappropriately held back and remained in the body for a long time, this too was perilous according to widespread conviction. Withheld semen - this Handsch learned from the Hippocratic aphorisms and from Avicenna - became highly noxious, indeed poisonous. ${ }^{611}$ Particularly imperiled were virgins, nuns, and widows, but men too had to reckon with grave consequences for their health if they lived too abstemiously. The seminal substance that in its natural condition was especially pure and valuable was for that very reason particularly inclined to decompose and to release very harmful, in fact poisonous substances if it built up in the body. Just before her (unexpected) death, Gallo advised the chronically ill Baroness of Hungerkasten, whose complaints were numerous, to lie with her husband. ${ }^{612}$ As Handsch noted, even sexual dreams ("insomnia Veneris"), which, according to Handsch, women certainly had as well, could have grave consequences. While, for men, the semen left the body, the dreaming woman's seed only passed into the uterus. Because no conception took place, the seed could easily spoil and give rise to the most severe illnesses ("maximos morbos"). ${ }^{613}$

The dangers posed by withheld, corruptible semen constituted an important reason why physicians recommended marriage, especially to women. Moreover, coitus warmed the blood and encouraged the evacuation of spoiled blood via the uterus, that is, via menstruation. ${ }^{614}$ For these reasons, Gallo told a sick virgin, for example, that a husband would be a "good cure" for her cough, hardened splenic tumor, and disrupted menstruation. ${ }^{615}$ Handsch himself gave this advice to an unmarried young woman in Trento. He also added that a clergyman whose name he did not mention and who also worked as a physician had given this advice to women. ${ }^{616}$ The idea was common among laypeople as well. The abovementioned Dr Andreas in Ambras thought that his unmarried sister, with her heavy feet, languidness, shortness of breath, pain in her loins, and insufficient menstrual bleeding, had little hope of recovery if she did not marry soon. ${ }^{617}$ According to Handsch,

610 Sächsische Landes- und Universitätsbibliothek Dresden, Ms. C337, “Consilia praestantissimorum aliquot in Gallia medicorum", foll. 292v-294v: "Pro quodam adolescente gonorrhoea laborante, ex mastupratione et praematuro veneris usu."

611 Cod. 11205, fol. 165r; Cod. 11207, fol. 37v.

612 Cod. 11183 , fol. $22^{\star}$, added slip of paper.

613 Cod. 11210, fol. 9v.

614 Cod. 11207, fol. 209r.

615 Ibid., fol. 83r.

616 Ibid.

617 Cod. 11183 , fol. 388v. 
a monk had said to a woman, "All of your illness is that you have no desire for men", and it appeared that she agreed. ${ }^{618}$ The understanding sketched out here was also presumably at the root of a comment made by an archducal chancery clerk, who said his wife, plagued as she was by pain and a white discharge, lay like a tree trunk ("tanquam truncum") during coitus; this indicated lacking desire and thus an insufficient emission of her accumulated seed. ${ }^{619}$

The idea, then, was to find the proper balance. As long as one did not overdo it, coitus was healthy for body and spirit - this Handsch gleaned from his reading. It relieved the body, strengthened the appetite, alleviated mental upset, and was useful for sad and melancholy people, epileptics, and people with phlegmatic illnesses. ${ }^{620}$ As physicians knew from their reading, the notion that coitus helped those suffering from melancholy in particular had already found expression in the work of Galen. ${ }^{621}$ Thus Gallo could only agree with an old woman who urged those suffering from melancholy to have intercourse frequently. He himself had actually given this advice before. ${ }^{622}$ Gallo explicitly advised the young, unmarried Archduke Ferdinand to have intercourse because he attributed his unusual complaints - which some considered to have possibly been inflicted by witchcraft, while others saw them as the result of melancholy to withheld seed. ${ }^{623}$ Handsch, however, was not prepared to believe this. Even a nun, he felt, would know how to help herself in this situation, and certainly a young prince would. ${ }^{624}$

Handsch also carefully observed the effects the discharge of semen had on his own body. When, over the course of two days, he observed that his pulse was irregular - there were short interruptions and sudden quick beats - he wondered if this could be the result of withheld semen, even though, he added, he had masturbated earlier. ${ }^{625}$ When he was suffering acutely from a bladder stone, it appears he hoped he might ease the egress of the stone in this way. After a previous manuductio - this was the term that he commonly used for

617 Cod. 11183 , fol. $388 \mathrm{v}$.

618 Cod. 11205, fol. 211r.

619 Cod. 11183, fol. 460r.

$620 \mathrm{Cod}$. 11210, fol. 66v; at another point, however, he explained that as a general rule epileptics should be forbidden to have sexual intercourse because it weakened the nerves (Cod. 11240, fol. 88r).

621 Cod. 11207, fol. 43r, referring to Galen's commentary on the Hippocratic Aphorisms (book 5, ch. 5).

622 Ibid.

623 Cod. 11204, fol. 37r.

624 Cod. 11207 , fol. $37 \mathrm{v}$.

625 Cod. 11205, fol. 218r. 


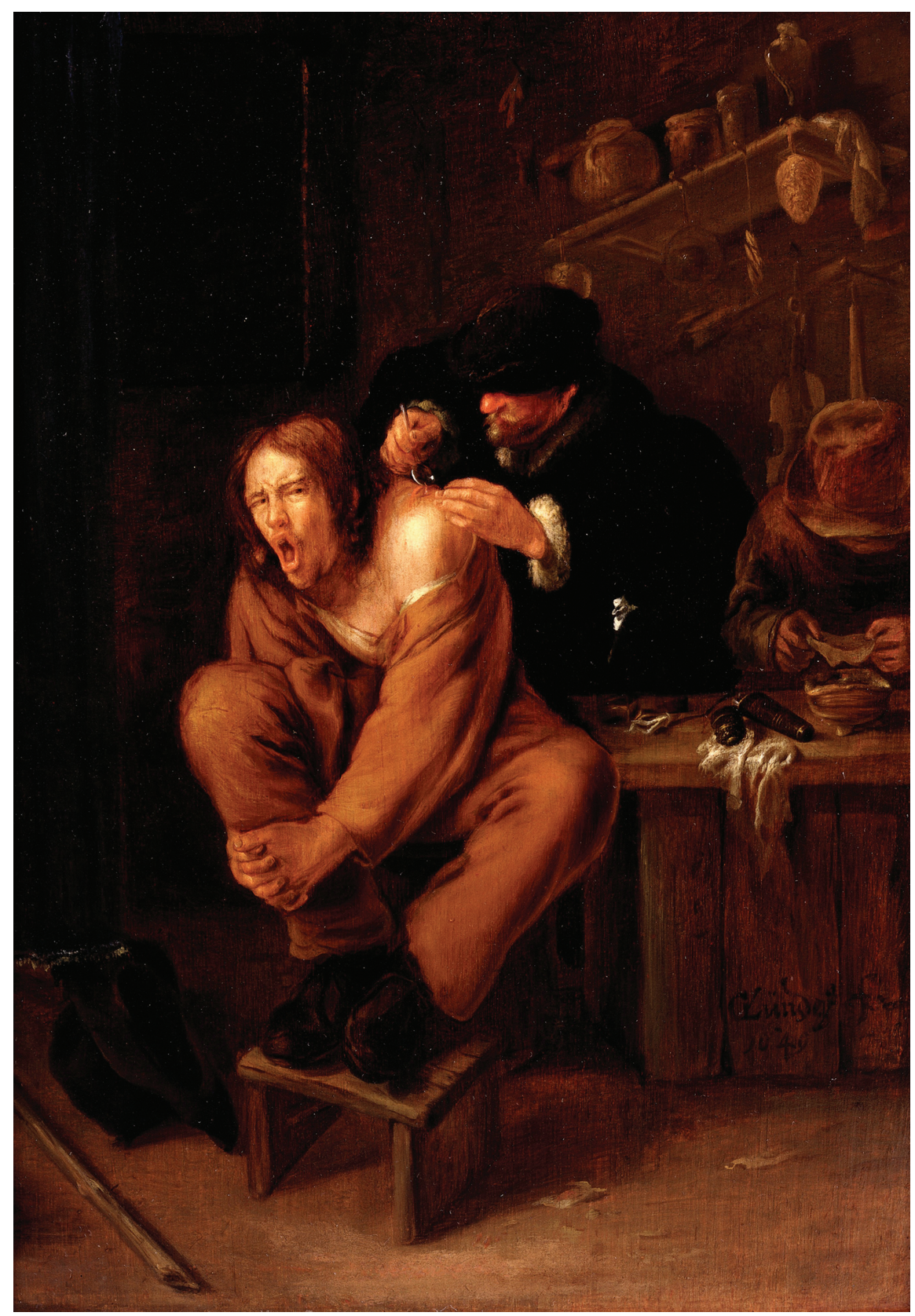

Fig. 7: Painful surgical treatment, oil painting by Gerrit Lundens, 1649, Wellcome Collection, London. 
masturbation - earlier in the day, he "forced" a second ejaculation in the evening. ${ }^{626}$ As his stone disease progressed, however, he eventually decided that he would forgo a manuductio after his midday nap and after his evening meal. ${ }^{627}$ He experienced that the spermatizatio also had a weakening effect; after having masturbated upon going to bed, he was "weak and exhausted", and it surprised him that he nevertheless had sexual dreams. ${ }^{628}$

\section{Surgery}

Surgery was an important branch of medicine and had been firmly established in the medical literature since the Middle Ages. ${ }^{629}$ In the sixteenth century, its significance in scholarly medicine grew further, in part thanks to the growing field of anatomy, which was predominantly practiced by surgically experienced physicians. Regarding the status of surgery in medical practice, however, there were great differences within Europe, as we have seen in Part I. In Italy, surgery was broadly recognized. It was taught at universities, sometimes by doctors of medicine such as Gabrielle Falloppia, who also had extensive practical experience in surgery. In German-speaking areas by contrast, surgery was considered the domain of the barber-surgeons (cf. Fig. 7). who were trained as craftsmen and who guarded their guild's privileges, making it difficult for non-members, including the doctores medicinae, to gain a foothold in the field.

In the understanding of the time and certainly in the German-speaking areas, surgeons were in charge of "external", manual treatments - terms like "chirurgia" or "Chirurgie" come from the Greek words for "hand" and "work". This included not only the treatment of wounds and fractures but also minor interventions such as bloodletting, cupping, and giving enemas or clysters, along with the treatment of tumors, skin rashes, and ulcers. The medical doctors for their part staked out their territory: the administering of medications for internal use. When it came to the few major, high-risk surgeries that were possible in the circumstances - mainly cutting stones, operating on hernias, and couching - these were primarily the realm of specialized itinerant surgeons. ${ }^{630}$

626 Cod. 11183, fol. 434v, "iterum modo cogens quasi".

627 Ibid., fol. 459v.

628 Cod. 11205, fol. 80v, "cum ad introitum lectum spermatizavi, postea in somno etiam somniavi venera, quamvis ad primam spermatizationem iam debilis et exhaustus spermate fui."

629 Pouchelle, Body (1990); McVaugh, Rational surgery (2006).

630 Jütte, Ärzte (1991), pp. 20-23. 
As Handsch's notes show, the lines between the surgeon's and the physician's area of activity were ultimately blurred in everyday medical practice north of the Alps, as in other parts of Europe. For one thing, many barber-surgeons did not limit themselves to surgical procedures but practiced medicine as a whole, and they often administered medicines intended for internal use. ${ }^{631}$ Even highranking rulers sometimes preferred the help of a barber-surgeon to tend to their internal diseases, and Handsch, too, occasionally sought their treatment. Not only this, but doctors of medicine indeed explored surgical matters and surgical cases at length. North of the Alps, they took up the surgical knife only as an exception but if they wanted to present themselves to their patients as competent experts who could deal with any case, they had to at least know how surgical diseases were diagnosed and treated, and they had to be able to give the barber-surgeons instructions if necessary, and to supervise them. In serious cases, especially with high-ranking patients and their staff, learned doctors and barber-surgeons sometimes even cooperated. For example, Mattioli worked with "the barber-surgeons" when he treated the abdominal injury of a certain Virgilius, who was apparently in the service of the Archduke. The man was very unwell. Stool came out of his wound and Mattioli thought that his subdued cough, his difficulty breathing, and occasional expectoration of blood indicated the injury of a lung. ${ }^{632}$

Handsch's notes about medical practice include dozens of entries about surgical cases. Sometimes he only briefly described cases which his teachers, mentors, and colleagues had apparently treated in his presence, for example, the treatment of a fractured shin by Ulrich Lehner ${ }^{633}$ or Tremenus's visit to a young man with a head wound. ${ }^{634}$ Many of Handsch's entries, however, are very specific and are concerned with craftsmanship and detailed technical knowledge. For example, Lehner taught him how to keep ulcers from closing over prematurely by inserting gentian root. The root swelled, thus dilating the opening. ${ }^{635}$ If an ulcer healed prematurely, it was feared that the morbid matter, which until then had been evacuated via the ulcer, would accumulate inside the body. ${ }^{636}$ Handsch could thank Mattioli for his recipes for various remedies, which he used on surgi-

631 See Staatsbibliothek Berlin, Hdschr. 442, Arzneybuch of the bathmaster Hanns Triefseysen.

632 Cod. 11207, fol. 161r-v

633 Cod. 11247, fol. $27 \mathrm{v}$.

634 Cod. 11226, fol. $175 \mathrm{v}$.

635 Cod. 11183, fol. 39v.

636 Cod. 11205, fol. 521v. 
cal cases, for example the recipe for a poultice against burns. ${ }^{637}$ He also took note of different forms of dressings, which he saw others use, such as a crossed linen bandage slung around the wrist and tied for finger injuries. ${ }^{638}$

But above all,Handsch learned from the craftsmanship of the barber-surgeons, even when he was an experienced physician. These were the professionals who were so violently criticized for their alleged incompetence and ignorance by Paracelsus, Johannes Lange, and other contemporary authors. Handsch's most important source of knowledge for surgical matters was the archducal court surgeon Hildebrand. Hildebrand showed him, for example, where to place the incision when treating an empyema, that is an accumulation of pus in the ribcage. ${ }^{639}$ Handsch also noted down multiple times how Hildebrand proceeded in the examination and treatment of severe injuries and deep ulcers. For example, he wrote a detailed account of how Hildebrand and the barber Melchior Störl, working together, treated a young man in Ötting who, in a state of inebriation, had incurred serious head injuries and wounds on his back and arm. With their instruments, they did a thorough examination of his head injuries until the man fainted from pain, or rather seized. They brought him to again by having him smell vinegar and put a spoon in his mouth, apparently so he could clench his teeth without hurting himself. The following day, Hildebrand probed the skull again, using one of his instruments. He discovered a place where the skull was fractured and moved a bone fragment that had been pushed inward back into its proper position. The patient recovered. ${ }^{640}$ It was also Hildebrand who examined the ulcerating tumor on the upper abdomen of the terminally ill Anna Welser with a silver pin to determine how far it extended inward. ${ }^{641}$

As a court surgeon, Hildebrand was quite a prominent figure compared to the majority of ordinary barber-surgeons. But Handsch also conversed with a barber about bleeding control during a leg amputation. From him, Handsch learned that he would not cauterize the surface of the wound, as was widely practiced at the time, but would instead fold a wet bladder over it, likely meaning the application of a poultice. ${ }^{642}$ Handsch also found it worthwhile to note down what another barber told him about stonecutting: in the case of a bladder stone, he did not insert his finger in the anus to feel the stone in the bladder, but instead

637 Cod. 11183 , fol. $164 \mathrm{r}$.

638 Ibid., fol. 165 r.

639 Ibid., fol. $468 \mathrm{v}$.

640 Ibid., fol. 354r-v; Handsch did not explicitly mention that he could witness the operation but his detailed description leaves little doubt that he did.

641 Ibid., fol. 430r-v.

642 Ibid., fol. 22v. 
found the stone with a probe, made his incision, and lifted the stone out with pliers. ${ }^{643}$ Handsch further described how a barber in Ambras carefully inspected a chest wound that a guard had inflicted on a tailor, and concluded that the weapon had not penetrated to the inside of the chest and that the patient was not "weydwund", was not fatally wounded in other words. ${ }^{644}$

Handsch took notes for one of the standard surgical procedures of the time in particular detail, the creation of a fontanella, an artificial ulcer that was kept open to allow for the continuous drainage of morbid matter. It seems he had the opportunity to watch a barber do it. The barber applied a small, round plaster, about four fingerwidths back from the edge of the tibia, so as not to risk hurting any nerves and tendons. The plaster had a small opening in the middle, into which the barber put a paste of Spanish flies and then applied a dressing. He then let the paste act upon the skin for ten hours or more. When a blister had formed, he cut it off with scissors, put in elder pith ("medulla sambuci") and lead into the open wound and again dressed the area. The next morning, he removed the elder pith, which had already taken up quite a bit of liquid. In the evening, he filled the now larger opening again with the same paste. This procedure was repeated for several days. When, finally, the scab fell off and an ulcer had formed, he put a small hollow silver sphere about the size of a hazelnut into the opening to keep it open. ${ }^{645}$

From the barber-surgeons, Handsch also learned about medications they used successfully in the treatment of external complaints and injuries. One of them applied a "white ointment" ("unguentum album") on a bruise which a clerk had incurred over his eye. This was a standard remedy. At this opportunity Handsch also learned that it could be used for decubitus or pressure sores ("ad excoriationem a iactura") as well. ${ }^{646}$ And Handsch furthermore accepted the critique of a barber who pointed out a mistake to him. Handsch had applied the unguentum album to the wound of a little girl who had fallen. In his notes on the case he added "error" and includes the barber's question, "What is the white ointment to do, when [the wound] is open."647

Sometimes, Handsch even found it worthwhile to write down the experiences and knowledge of medical laypeople in surgical matters. For example, a woman

643 Ibid., fol. 211r.

644 Ibid., fol. 372v; Handsch did not indicate the reason why the guard injured the man.

645 Cod. 11207, fol. 216r-v; in another entry (Cod. 11183, fol. 131v), he also noted the recipe for the etching stone, the lapis corrosivus, which the surgeon Cunradus used on von Wartenberg's wife to create an ulcer (fontanel).

646 Cod. 11183, fol. 40v.

647 Ibid., fol. 165r. 
called the Bögnerin told him that her husband would put a small piece of cloth with glue ("glutine") on his finger after he had cut himself and then the wound would heal. ${ }^{648} \mathrm{He}$ also had a baker show him the truss he put on for his hernia, which the baker said he had incurred from carrying heavy things. Handsch described its form and design in great detail and even made a small drawing of it. ${ }^{649}$ And he took seriously what a stonecutter told him about the treatment of gangrene. The stonecutter's mother suffered from the "cold burn" and the barber-surgeons had already talked about amputation. But the stonecutter applied a remedy made of alum, frankincense, and myrrh and his mother recovered. ${ }^{650}$ Even when one of Handsch's landlords recommended placing a still warm, black-plumed hen with its rump cut off over the operation wound after a hand amputation, he took this seriously enough to write it down without commentary. ${ }^{651}$

Several times Handsch sought out and found the opportunity to watch experienced surgeons doing major, invasive procedures and examining and treating serious injuries. He gave a thorough description, for example, of the surgery on a forty-five-year-old servant ("famulus"). The man had had an intestinal hernia for seven years and it had become larger and larger. The surgery took half an hour. First of all, everyone present bent their knees and prayed to God. Then the surgeon placed three incisions and removed the testicle - which was common practice in such cases. The patient fainted. When he regained consciousness, the surgeon asked him a few questions and cauterized the area with a red-hot iron. Handsch quoted the patient saying that this was what hurt him the most. But he had not wanted to get drunk - apparently, this was how some people dealt with the pain of the operation. He had only consumed some spiced wine. Following the procedure, he had to stay in bed for five weeks, but he survived the surgery and the hernia was gone.

Handsch also witnessed the surgical removal of a hernia or hydrocele with a six-year-old boy. The procedure took less than half an hour. The boy was tied head down to a board or beam which was placed at an angle, likely so the intestines would recede as far as possible into the abdomen through their own weight. The boy cried pitifully from the pain. After the operation, he had the cold sweat of fear on his face but was able to walk on his own feet to go to bed. ${ }^{652}$ It is likely that Handsch was also present when a surgeon operated on his 13-year-old halfbrother Johannes, successfully removing an almost chicken-egg sized bladder

648 Ibid., fol. $211 \mathrm{r}$

649 Cod. 11205, fol. $126 \mathrm{v}$

650 Cod. 11183, fol. 2v.

651 Ibid., fol. 297r.

652 Cod. 11204, fol. 16r 
stone within a quarter of an hour. ${ }^{653}$ He only had somebody else's account, however, of the leg amputation a barber performed on an older man in Prague's Angel's Garden. The barber had promised that three blows of the hatchet would be enough - he apparently did not use a saw. In the end, he took almost thirty blows, tormenting the man like a torturer. He was at least able to stanch the blood without using a cautering iron. He only "pinched the veins with wire". The man died three days later. ${ }^{654}$

It has been widely assumed in historical research that learned physicians north of the Alps, generally did not perform surgical interventions themselves. As a student, Handsch made a point of writing down Galen's admonition that a physician was never to perform surgery but must instead only prescribe it, just as the emperor did not fight at the front of his army with a sword but gave the army orders. ${ }^{655}$ Once again, however, a more differentiated picture emerges when we look at everyday medical practice more closely. When it came to minor surgery, Handsch certainly did occasionally take up the knife. He sometimes even gave clysters, though this was typically a task for the barber-surgeons. He learned at this opportunity that it was not the easiest task. Importantly, he found that the person administering the clyster or an assistant had to make sure that the clyster did not slip back out of the anus from the pressure. It had happened to him. Perhaps it was better, he reflected, to wrap the tip of the clyster syringe with fine leather, which he had seen done in Trento. This way, the syringe did not slip out of the anus as easily. ${ }^{656}$ He furthermore mentioned - repeatedly, and without further explanation - surgical cases that he treated himself, for example the case of a certain Hans Reutter, who had been bitten by a dog. ${ }^{657}$

Handsch's training in Italy may have caused him to be particularly open toward surgery but he shared this Italian experience with many other physicians from north of the Alps. There we find indications that other learned physicians, too, who treated surgical cases and even performed surgical procedures personally. For example, Handsch wrote that his colleague Willenbroch had "cauterized the area”. Willenbroch was treating a man who had mistakenly taken a big gulp of corrosive sublimate thinking it was wine. In time, a bulge had formed in his upper abdomen, which was hard to the touch like a drum. The area was first opened with a caustic agent ("ruptorium") and then with a lancet. A silver canula was inserted

653 Cod. 11183, fol. 211r.

654 Cod. 11205, fol. 492v.

655 Cod. 11231, fol. Ir, with a reference to Galen's commentary on the sixth book of Hippocratic Epidemics.

656 Cod. 11205, fol. 147v, "ego clysterizavi”.

657 Cod. 11183, fol. 369r. 
and it was said that close to forty pounds of blood and pus were passed in the course of a month. ${ }^{658}$

Already in the sixteenth century, several physicians north of the Alps even possessed extensive surgical knowledge and skill. In most cases, they likely owed their expertise to having trained as surgical craftsmen or having studied in Italy. Volcher Coiter, for example, who had earned his doctorate in Bologna, spent more than ten years in Italy, and in 1569 he was appointed the municipal physician and surgeon of Nuremberg. ${ }^{659}$ As early as 1560, Steffan Holtman had been employed as a "medical and surgical doctor" with the express condition that he be "willing and ready to let himself be put to use as a surgeon". ${ }^{600}$ And even the municipal physician of Fulda, Burkhard Schönfeld, who is not known to have undergone special surgical training or to have studied in Italy, wrote in 1597 about "instrumentis meis chyrurgicis", and so it appears that he at least had his own set of surgical instruments.

658 Ibid., fol. 412v, "urebat ipsum hic locus"; in the individual case, such wording always leaves open the possibility that the doctor in question merely gave the order for such an operation, however.

659 Groß/Steinmetzer, Strategien (2005), p. 280.

660 Wolfangel, Ayrer (1957), pp. 60-62, edition of the contract. 